\title{
Profil Sensititifitas Antibiotik Pada Penderita Infeksi Saluran Kemih Di RSUD Prof. Dr. W. Z. Johannes Kupang Tahun 2017
}

\author{
Meryani H. Nisnoni ${ }^{1}$, Yorida F. Maakh ${ }^{2}$ \\ Prodi Farmasi Poltekkes Kemenkes Kupang \\ Email : yobalukhmaakh@gmail.com
}

\begin{abstract}
Abstrak
Resintensi bakteri dapat menyebabkan kegagalan dalam pengobatan penyakit infeksi salah satunya adalah infeksi saluran kemih (ISK). Sasaran terapi pada saluran kemih adalah mikroorganisme penyebab infeksi, maka pengobatan ISK sebagian besar menggunakan antibiotik. Rumah Sakit merupakan tempat penggunaan antibiotik paling banyak ditemukan, salah satunya adalah RSUD Prof. Dr. W.Z. Johannes Kupang. Pengobatan penyakit infeksi dengan antibiotik harus dilakukan pemilihan kelas antibiotik yang tepat. Untuk memilih antibiotik yang tepat perlu diketahui tingkat resistensi bakteri terhadap antibiotik tertentu, dengan melihat hasil uji sensitifitas antibiotik terhadap bakteri. Adapun tujuan dari penelitian ini adalah untuk mngetahui antibiotik yang diberikan kepada pasien penderika ISK dan untuk mengetahui persentase sensitifitas antibiotik terhadap tiap - tiap jenis bakteri penyebab ISK di RSUD Prof. Dr. W.Z. Johannes Kupang periode Januari - Desember 2017. Jenis penelitian yang dilakukan adalah penelitian yang bersifat deskriptif yaitu data dikumpulkan secara retrospektif dari catatan hasil kultur urin dan uji sensitifitas yang didapatkan dilaboratorium bakteriologi RSUD Prof. Dr. W.Z. Johannes pada bulan Januari - Desember 2017 dianalisis dalam bentuk tabulasi dan grafik kemudian dideskriptikan. Hasil Penelitian menunjukan bahwa antibiotik yang paling banyak digunakan adalah Gentamycin dan Ceftazidime.
\end{abstract}

\section{Kata kunci : ISK, Kultur Urin, Uji Sensitifitas, Antibiotik}

\section{PENDAHULUAN}

Penggunaan antibiotik yang tepat dibutuhkan untuk mengatasi masalah resistensi antibiotik. Menurut Soemohardjo (2009), prinsip dasar penggunaan antibiotik rasional yaitu tepat indikasi, tepat penderita, tepat pemilihan jenis antibiotik, tepat dosis, efek samping minimal, bila diperlukan ada kombinasi antibiotik secara tepat, dan ekonomik. Bakteri telah menjadi resisten terhadap antibiotik dalam lima tahun terakhir (Tjay \& Rahardja, 2007).

Bahaya resistensi antibiotik merupakan salah satu masalah yang dapat mengancam kesehatan masyarakat. Bakteri yang telah mengalami resistensi terhadap antibiotik ini dapat menyebar ke anggota keluarga, teman, tetangga ataupun orang lain sehingga mengancam masyarakat akan hadirnya jenis penyakit infeksi baru yang lebih sulit untuk diobati dan membuat biaya pengobatan menjadi lebih mahal (Badan, 2011).

Upaya untuk memaksimalkan penggunaan antibiotik yang tepat merupakan salah satu tanggung jawab penting dari pelayanan farmasi. Hal yang dapat dilakukan diantaranya adalah menetapkan dan melaksanakan (bersama dengan staf medis) suatu program evaluasi penggunaan antibiotik secara terus-menerus (Siregar, 2005).

Seorang farmasis mempunyai peran penting dalam peningkatan kualitas penggunaan antibiotik. Hal inilah yang mendorong peneliti untuk meneliti ketepatan penggunaan 
antibiotik pada pasien infeksi saluran kemih Infeksi saluran kemih (ISK) merupakan salah satu penyakit infeksi yang paling banyak terjadi. Infeksi saluran kemih merupakan salah satu jenis infeksi nosokomial yang angka kejadiannya paling tinggi di Indonesia yaitu sekitar 39\%-60\% menurut hasil penelitian yang dilakukan di dua kota besar di Indonesia. Data dari survey yang dilakukan oleh kelompok peneliti AMRIN (Anti Microbal Resistance In Indonesia ), di RSUP Dr. Kariadi Semarang tahun 2002, angka kejadian ISK merupakan yang paling tinggi yaitu 11\% (Kasmad, 2007).

Infeksi saluran kemih (ISK) adalah infeksi bakteri yang terjadi pada saluran kemih (mencakup organ organ saluran kemih, yaitu ginjal, ureter, kandung kemih, dan uretra). Infeksi saluran kemih di Indonesia insiden dan prevalensinya masih cukup tinggi. Keadaan ini tidak terlepas dari tingkat dan taraf kesehatan masyarakat Indonesia yang masih jauh dari standart dan tidak meratanya tingkat kehidupan sosial ekonomi.

Infeksi Saluran Kemih (ISK) merupakan penyakit yang sering dijumpai di masyarakat, menyerang anak-anak maupun dewasa dan merupakan masalah kesehatan yang serius.Pada umumnya pasien ISK lebih banyak dijumpai pada wanita dibanding pada pria kemungkinan karena uretra wanita lebih pendek sehingga mikroorganisme dari luar lebih mudah mencapai kandung kemih dan juga letaknya dekat dengan daerah perianal dan vagina. Sasaran terapi pada infeksi saluran kemih adalah mikroorganisme penyebab infeksi. Oleh karena itu, pengobatan ISK sebagian besar menggunakan antibiotik.
Rumah sakit merupakan tempat penggunaan antibiotik paling banyak ditemukan,dan RSUD Prof. Dr. W.Z. Johannes adalah salah satu rumah sakit yang berada di NTT yang menggunakan antibiotik pada pelayanan. Pemilihan antibiotik untuk pengobatan didasarkan pada tingkat keparahan, tempat terjadinya infeksi dan jenis mikroorganisme yang menginfeksi. Mempertimbangkan terjadinya fenomena resistensi antibiotika pada kuman penyebab ISK yang relatif cepat, maka profil sensitifitas antibiotika yang tepat akan sangat mendukung efektivitas terapi selain rute pemberian dan lama pemberian antibiotika, serta hal-hal lain yang termasuk dalam kriteria pemakaian obat secara rasional.

Penelitian tentang profil sensitifitas antibiotika pada pasien ISK di RSUD Prof. W.Z. Johannes tahun 2013, dari 87 responden, Antibiotik yang paling banyak digunakan adalah ciprofloxacin (98,8\%). Antibiotik yang paling sensitif adalah meropenem $(93,98 \%)$, Escherichia coli, Klebsiella pneumonia, dan Enterobacteriaceae group bacteria. Antibiotik yang paling resisten adalah ampisilin $(87,14 \%)$ (Hilaria, Elisma, Yuliani, \& M., 2018).

Pengobatan infeksi saluran kemih sebagian besar lebih dititik beratkan pada penggunaan antibiotik. Antibiotik yang dipakai untuk ISK pada azasnya harus memenuhi beberapa syarat selain aktif terhadap bakteri penyebab, yaitu harus mempunyai kadar dalam kemih yang tinggi dan kadar dalam darah yang rendah, serta tidak boleh mengganggu resistensi kolonisasi dari usus besar (Tjay dan Rahardja, 2007). Berdasarkan uraian diatas maka peneliti melakukan penelitian Profil Sensitifitas Antibiotik pada Pasien Infeksi Saluran Kemih (ISK) di 
RSUD. Prof. Dr. W. Z. Johannes Kupang Periode Januari sampai dengan Desember Tahun 2017.

\section{METODE PENELITIAN}

Jenis penelitian ini adalah penelitian deskriftif. Penelitian dilakukan di laboratorim di Laboratorium Bakteriologi RSUD Prof. Dr. W. Z. Johannes Kupang pada bulan April dan Mei 2018. Pasien pada penelitian ini adalah pasien yang positif infeksi saluran kemih hasil dari kultur urin di Laboratorium Bakteriologi RSUD Prof. Dr. W. Z. Johannes Kupang dari bulan Januari sampai dengan bulan Desember 2017.

\section{Prosedur Penelitian}

Penelitian dimulai dengan pembuatan surat permohonan dari kampus kepada Direktur RSUD Prof. Dr. W. Z. Johannes Kupang untuk melakukan penelitian atau pengambilan data di laboratorium bakteriologi di RSUD Prof. Dr. W. Z. Johannes Kupang.

\section{Pengolahan dan Analisa Data}

Cara pengolahan data dan menganalisa data dalam penelitian ini adalah data dikumpulkan secara retrospektif dari catatan hasil kultur urin dan uji sensitifitas yang didapatkan di Laboratorium Bakteriologi RSUD Prof. Dr.W.Z. Johannes Kupang dan dianalisis dalam bentuk tabulasi dan grafik kemudian dideskripsikan.

\section{HASIL DAN PEMBAHASAN}

Telah dilakukan profil sensitifitas antibiotik pada penderita Infeksi saluran kemih di RSUD prof. Dr. W.Z. Johannes kupang tahun 2017.

\section{Karakteristik Pasien}

Penderita Infeksi saluran kemih di RSUD prof. Dr. W.Z. Johannes kupang tahun 2017 sebanyak 47 orang, dengan jumlah perempuan 29 orang $(61,70 \%)$ dan Laki-laki 18 orang $(38,30 \%)$. Hal ini dapat disebabkan karena perbedaan struktur anatomi genitourinari antara perempuan dan laki-laki dimana uretra perempuan yang lebih pendek sehingga bakteri kontaminan lebih mudah memperoleh akses ke kandung kemih. Faktor lain yang berperan adalah kecendrungan menahan urin dan iritasi pada kulit uretra perempuan pada saat berhubungan kelamin.

Tabel 1. Distribusi Pasien penderita Infeksi Saluran Kemih menurut Umur dan Jenis Kelamin d RSUD Prof. Dr. W.Z. ohanes Kupang Periode Januari-Desember 2017

\begin{tabular}{|l|c|c|c|c|c|}
\hline $\begin{array}{c}\text { Rentang } \\
\text { Umur } \\
(\text { Thn) }\end{array}$ & Jml & $\%$ & Jml & $\%$ & Total \\
\cline { 2 - 5 } $\begin{array}{l}\text { Anak } \\
(<12 \\
\text { thn) }\end{array}$ & 1 & 33,33 & 2 & 66,66 & 3 \\
\hline $\begin{array}{l}\text { Remaja } \\
(12-21 \\
\text { Th) }\end{array}$ & 0 & 0 & 3 & 100 & 3 \\
\hline $\begin{array}{l}\text { Dewasa } \\
\left(\begin{array}{l}\text { (22-59 } \\
\text { Th) }\end{array}\right.\end{array}$ & 14 & 36,80 & 24 & 63,20 & 38 \\
\hline $\begin{array}{l}\text { Tua } \\
(<59 \text { Th })\end{array}$ & 3 & 100 & 0 & 0,00 & 3 \\
\hline
\end{tabular}

Pasien terbanyak yaitu kisaran umur 22 sampai dengan 59 tahun yaitu sebanyak 38 Pasien $(80,80 \%)$ yang terdiri dari 24 pasien $(63,20 \%)$ perempuan dan 14 Pasien $(36,80 \%)$ laki-laki. Hasil ini hampir sama dengan penelitian yang dilakukan oleh Amin et al (2009) di Rumah Sakit Ahvas Iran dimana pasien terbanyak yang terkena Infeksi Saluran Kemih adalah pasien dengan kisaran umur 2560 Tahun (Amin, Mehdinejad, \& Pourdangchi, 2009).

\section{Bakteri Penyebab Infeksi Saluran Kemih}


Tabel 2 menunjukan bahwa dari hasil kultur urin , lima besar bakteri yang paling banyak ditemukan yaitu Escherichia coli (29,2\%), kedua adalah Candida albicans (13,8\%), ketiga adalah Klebsiella pneumoniae ss (12,3\%), keempat adalah Acinetobacter baumannii $(7,7 \%)$, dan kelima adalah golongan Enterobacter $(9,3 \%)$. Hasil ini hampir serupa dengan penelitian yang dilakukan oleh Imaniah (2015) bahwa bakteri penyebab ISK di RSUD Dr. Moewardi yaitu bakteri Escherichia coli (48,44\%), Klebsiella pneumoniae ss (17,19\%), Acinetobacter baumannii $(14,07 \%)$ (Rahmawati, 2015).

Tabel 2. Distribusi Bakteri Hasil Kultur Urin Pasien ISK di RSUD Prof. Dr. W.Z. Johannes Kupang Periode Januari - Desember 2017

\begin{tabular}{|l|l|c|c|}
\hline Sandi & \multicolumn{1}{|c|}{ Organisme } & $\begin{array}{c}\text { Jumlah } \\
\text { Isolat }\end{array}$ & $\begin{array}{c}\% \\
\text { Pasien }\end{array}$ \\
\hline aba & $\begin{array}{l}\text { Acinetobacter } \\
\text { baumannii }\end{array}$ & 5 & 7,7 \\
\hline cal & $\begin{array}{l}\text { Candida } \\
\text { albicans }\end{array}$ & 9 & 13,8 \\
\hline cfr & $\begin{array}{l}\text { Citrobacter } \\
\text { freundii }\end{array}$ & 1 & 1,5 \\
\hline ecl & $\begin{array}{l}\text { Enterobacter } \\
\text { cloacae }\end{array}$ & 4 & 6,2 \\
\hline eco & Escherichia coli & 19 & 29,2 \\
\hline en- & Enterobacter sp. & 2 & 3,1 \\
\hline ent & $\begin{array}{l}\text { Enterococcus } \\
\text { sp. }\end{array}$ & 2 & 3,1 \\
\hline kkr & $\begin{array}{l}\text { Kocuria } \\
\text { kristinae }\end{array}$ & 1 & 1,5 \\
\hline mmo & $\begin{array}{l}\text { Morganella } \\
\text { morganii } \\
\text { Morganii }\end{array}$ & 1 & 1,5 \\
\hline Pae & $\begin{array}{l}\text { Pseudomonas } \\
\text { aeruginosa }\end{array}$ & 2 & 3,1 \\
\hline Pce & $\begin{array}{l}\text { Burkholderia } \\
\text { cepacia }\end{array}$ & 1 & 1,5 \\
\hline Pfl & $\begin{array}{l}\text { Pseudomonas } \\
\text { fluorescens }\end{array}$ & 1 & 1,5 \\
\hline Pmi & $\begin{array}{l}\text { Proteus } \\
\text { mirabilis }\end{array}$ & 2 & 3,1 \\
\hline Ppu & Pseudomonas & 1 & 1,5 \\
\hline
\end{tabular}

\begin{tabular}{|l|l|l|l|}
\hline & putida & & \\
\hline Sau & $\begin{array}{l}\text { Staphylococcus } \\
\text { aureus ss. } \\
\text { Aureus }\end{array}$ & 1 & 1,5 \\
\hline Scn & $\begin{array}{l}\text { Staphylococcus, } \\
\text { coagulase } \\
\text { negative }\end{array}$ & 2 & 3,1 \\
\hline Sfo & $\begin{array}{l}\text { Serratia } \\
\text { fonticola }\end{array}$ & 1 & 1,5 \\
\hline Sma & $\begin{array}{l}\text { Serratia } \\
\text { marcescens }\end{array}$ & 1 & 1,5 \\
\hline Spa & $\begin{array}{l}\text { Sphingomonas } \\
\text { paucimobilis }\end{array}$ & 1 & 1,5 \\
\hline Jumlah & 65 & 100 \\
\hline
\end{tabular}

Hal ini juga diperkuat oleh hasil penelitian yang dilakukan oleh Surya (2013) bahwa Escherichia coli $(58,5 \%)$ merupakan penyebab utam ISK di RSUP Fatmawati, Jakarta Selatan.

\section{Pola Sensitifitas Antibiotik}

Analisis isolat dan identifikasi bakteri penyebab infeksi saluran kemih dari spesimen urin pasien Infeksi Saluran Kemih yang dilakukan di laboratorium Patologi Klinik RSUD Prof. Dr. W.Z.Johannes Kupang. Hasil kultur bakteri dari 47 pasien yang tumbuh diuji sensitifitasnya terhadap antibiotik Meropenem, Gentamisin, Kotrimoksasole, Ceftazidime, Amikacin, Ampicilin/ Sulbactam, Ampicilin, Ceftriaxon, Cephalothin, Tetracycline, Ciprofloxacin, Amoxicilin, Clindamicin, Vancomycin dan Erytromycin.

\section{a. Pola Sensitifitas Antibiotika Golongan Beta-laktam}

Antibiotik golongan beta-laktam adalah antibiotik yang memiliki kesamaaan komponen struktur berupa adanya cincin beta-laktam. Antibiotik golongan ini umumnya bersifat bakterisid dan aktif terhadap bakteri Gram positif maupun negatif. 
Tabel 3. Persentase Sensitifitas antibiotika golongan Aminoglikosida dan Tetracycline

\begin{tabular}{|l|c|c|}
\hline $\begin{array}{c}\text { Nama } \\
\text { Antibiotik }\end{array}$ & $\begin{array}{c}\text { \% } \\
\text { Sensitif }\end{array}$ & $\begin{array}{c}\text { \% } \\
\text { Resisten }\end{array}$ \\
\hline Amoxicilin & 50 & 50 \\
\hline $\begin{array}{l}\text { Amoxicilin+ } \\
\text { As. Klafulanat }\end{array}$ & 50 & 50 \\
\hline Ampicillin & 7,4 & 92,6 \\
\hline Ceftazidime & 35,5 & 62,3 \\
\hline Ceftriaxon & 28,9 & 71,4 \\
\hline Cephalothin & 27,3 & 72,7 \\
\hline Meropenem & 81,8 & 18,2 \\
\hline
\end{tabular}

Antibiotika golongan beta-laktam yang digunakan di RSUD Prof. Dr.W. Z. Johannes Kupang dan dilakukan uji kultur bakteri yaitu: Meropenem, Ceftazidime, Ampicilin, Ceftriaxon, Cephalothin, Amoxicillin, Amoxicillin / asam klafulanat. Dari hasil uji kultur bakteri terhadap antibiotik golongan betalaktam maka diperoleh data kecuali antibiotik meropenem semua antibiotik dari golongan beta-laktam memiliki tingkat resitensi terhadap bakteri diatas $50 \%$ (Tabel 3).

Antibiotika golongan beta-laktam yang digunakan di RSUD Prof. Dr.W. Z. Johannes Kupang dan dilakukan uji kultur bakteri yaitu: Meropenem, Ceftazidime, Ampicilin, Ceftriaxon, Cephalothin, Amoxicillin, Amoxicillin / asam klafulanat. Dari hasil uji kultur bakteri terhadap antibiotik golongan betalaktam maka diperoleh data kecuali antibiotik. Meropenem merupakan antibiotik golongan karbapenem yang berspektrum sangat luas, termasuk kuman Gram negatif dan Gram Positif, baik yang aerobik maupun anaerobik. Selain itu meropenem juga resisten terhadap berbagai jenis betalaktamase baik yang diperantarai oleh plasmid maupun kromosom.(FKUI, 2007). Karena sifat meropenem yang resisten terhadap betalaktamase dan sangat aktif terhadap bakteri penghasil betalaktamase ini, maka hasil kultur bakteri dari meropenem dapat menunjukan tingkat sensitifitas yang tinggi mencapai $(81,8 \%)$ dibanding denga antibiotik golongan beta-laktam lainnya.

Resistensi bakteri terhadap golongan beta-laktam seperti penisilin dan sefalosporin disebabkan karena bakteri memproduksi enzim betalaktam yang membuat ikatan dengan antibiotik dan kemudian membentuk hidrolisis betalaktam, bakteri akan membuka cincin beta-laktam dari penisilin dan sefalosporin yang mengakibatkan hilangnya sensitifitas antibiotik.

b. Pola sensitifitas antibiotik golongan Aminoglikosida dan Tetrasiklin

Antibiotik

golongan

aminoglikosida dan tetrasiklin yang digunakan di RSUD Prof. Dr.W. Z.Johannes Kupang dan dilakukan uji kultur bakteri yaitu: Gentamicin, Amikacin dan tetracyclin. Dari hasil uji kultur bakteri yang dilakukan maka diperoleh pada Tabel 4.

Tabel 4. Persentase Sensitifitas antibiotika golongan Aminoglikosida dan Tetracycline

\begin{tabular}{|l|c|c|}
\hline $\begin{array}{c}\text { Nama } \\
\text { Antibiotik }\end{array}$ & $\begin{array}{c}\% \\
\text { Sensitif }\end{array}$ & $\begin{array}{c}\% \\
\text { Resisten }\end{array}$ \\
\hline Amikain & 81,5 & 0 \\
\hline Gentamicin & 68,8 & 31,2 \\
\hline Tetracyclin & 18,75 & 81,25 \\
\hline
\end{tabular}

Gentamisin dan Amikasin merupakan antibiotika golongan Aminoglikosida yang diindikasikan untuk infeksi oleh kuman Gram negatif yang sensitif antara lain $E$. Coli, K.pneumoniae, P.aeruginosa, Serratia mercescens, Proteus, Salmonella, Enterobacter, S.aureus dan S.albus (FKUI, 2007) yang 
semuanya merupakan bakteri penyebab Infeksi Saluran Kemih (ISK) di Laboratorium Patologi Klinik RSUD Prof.Dr.W.Z.Johannes Kupang periode Januari-Desember 2017, sehingga diperoleh hasil sensitifitas dari kedua antibiotik tersebut cukup baik yaitu Gentamicin $(68,8 \%)$ dan Amikacin $(81,25 \%)$.

Tetracyclin bekerja dengan cara menghambat sisntetsis protein bakteri pada ribosomnya. Dari hasil uji bakteri diperoleh hasil bahwa $81,25 \%$ bakteri penyebab Infeksi Saluran Kemih di RSUD Prof.Dr.W.Z.Johannes Kupang periode Januari-Desember 2017 telah Resisten dengan tetracyclin. Hal ini karena pemakaian tetrasiklinyang telah umum dimasyarakat tanpa resep dokter dan tidak sesuai dengan dosis dan aturan penggunaan mengakibatkan tetrasiklin menjadi resisten.

\section{c. sensitifitas antibiotik golongan Fluorokuinolon.}

Antibiotik

golongan

fluorokuinolon yang digunakan di RSUD Prof. Dr. W. Z. Johannes Kupang dan dilakukan uji kultur bakteri yaitu: Ciprofloxacin. Antibiotik ciprofloxacin dan levofloxacin digunakan sebagai pilihan pertama untuk pengobatan ISK bagian atas (G. Katzung, B. Masters, \& J. Trevor, 2012), mekanisme kerja dari antibiotik golongan Fluorokuinolon adalah dengan cara membuat DNA bakteri terpotong-potong dan mencegah proses perbaikan DNA kembali (Kuswandi, 2011).

Dari uji bakteri diperoleh hasil ciprofloxacin yang sensitif terhadap bakteri penyebab Infeksi Saluran Kemih sebanyak 55,6\%, sedangkan yang telah resisten terhadap bakteri penyebab Infeksi Saluran Kemih yaitu 44,4\%. Resistensi bakteri terhadap golongan fluoroquinolon seperti Ciprofloxacin dan levofloxacin dapat terjadi karena mutasi dan resistensi silang (Katzung, 2007), hal ini didukung oleh penelitian yang dilakukan oleh Chytranyngtias disurabaya yang menunjukan tingkat resistensi E.colli terhadap ciprofloxacin sebesar $76,5 \%$, dimana E.Colli merupakan bakteri terbanyak penyebab Infeksi Saluran Kemih di RSUD Prof. Dr. W.Z.Johannes Kupang.

\section{d. Pola sensitifitas antibiotik lainnya}

Antibiotik lain yang digunakan di RSUD Prof. Dr. W. Z. Johannes Kupang dan dilakukan uji kultur bakteri yaitu: Trimetrophim/ Sulfametoksasole, Clindamicin, Erytromichin dan Vankomicin. Dari hasil uji kultur bakteri yang dilakukan maka diperoleh data seperti pada Tabel 5.

Tabel 5. Persentase Sensitifitas antibiotik lainnya

\begin{tabular}{|l|c|c|}
\hline $\begin{array}{c}\text { Nama } \\
\text { Antibiotik }\end{array}$ & $\begin{array}{c}\% \\
\text { Sensitif }\end{array}$ & $\begin{array}{c}\% \\
\text { Resisten }\end{array}$ \\
\hline Clindamicin & 66,6 & 33,3 \\
\hline Erytromicin & 50 & 50 \\
\hline Vancomicin & 100 & 0 \\
\hline $\begin{array}{l}\text { Trimetrophim } \\
\text { Sulfametoksasol }\end{array}$ & 34,9 & 65,1 \\
\hline
\end{tabular}

Antibiotik

Trimetrophim/

Sulfametoksasole bekerja dengan cara menghambat enzim pada alur sintesis asam folat dari proses reduksi dihidrofolat. Bakteri penyebab infeksi saluran kemih yang resisten terhadap bakteri Trimetrophim/ Sulfametoksasole sebanyak $65,1 \%$. Retensi bakteri terhadap trimetrophim/Sulfametoksasole terjadi karena berkurangnya permeabilitas sel dan kelebihan dihidrofolatreduktase. (Katzung,2007).

Clindamicin merupakan antibiotik golongan Linkomisin yang aktif 
terhadap S.aureus, S.pneumoniae, $S$.Viridans. dari hasil uji kultur bakteri diperoleh data bakteri yang sensitif terhadap clindamicin sebanyak $66.6 \%$ Erytromicin merupakan antibiotik golongan Makrolida yang bekerja dengan cara menghambat sintesis protein kuman dengan jalan berikatan secara reversibel dengan ribosomsubunit 50S, dan umumnya bakteriostatik, walaupun kadang bersifat bakterisid terhadap kuman yang sangat peka (FKUI, 2007) dari hasil uji kultur bakteri diperoleh data bakteri yang sensitif terhadap Erytromicin sebesar 50\%.

Vancomicin adalah antibiotik golongan Glikopeptida, obat ini hanya aktif terhadap kuman Gram positif, Khususnya golongan kokus dari hasil uji kultur bakteri diperoleh data bhwa vancomicin merupakan satu-satunya antibiotik yang sensitif $100 \%$ terhadap akteri penyebab Infeksi Saluran Kemih. Hasil ini dipengaruhi oleh sampel isolat yang diuji sedikt yaitu 2 sampel.

Profil sensitifitas antibiotik pada pasien ISK sangat penting untuk keberhasilan pengobatan Infeksi Saluran Kemih sehingga perlu adanya pengkajian ulang pada terapi pengobatan Infeksi Saluran Kemih untuk mencegah terjadinya resistensi bakteri terhadap Antibiotik. Evaluasi penggunaan antbiotik pada periode tertentu diperlukan berdasarkan pola kuman penyebab Infeksi saluran Kemih sehingga penggunaan antibiotik lebih efektif. Tidak dilihatnya data skunder yaitu Rekam Medik dalam penelitian ini tidak bisa dijadikan gambaran umum pada pengobatan ISK sehingga peneliti tidak bisa mencocokan kesesuaian terapi antibiotik pada ISK.

\section{SIMPULAN}

Berdasarkan hasil pengumpulan data didapatkan 47 pasien penderita Infeksi Saluran Kemih yang diuji kultur bakterinya di Laboratorium Patologi Klinik RSUD Prof. Dr. W. Z. Johannes Kupang Periode Januari Desember 2017, selanjutnya dievaluasi dan diperoleh hasil sebagai berikut :

a. Antibiotik yang paling sensitif terhadap bakteri penyebab Infeksi Saluran Kemih adalah Vancomicin ( $100 \%)$, Meropenem (81,8 \%) dan Amikasin (81,5\%)

b. Antibiotik yang paling resisten terhadapa bakteri penyebab Infeksi Saluran kemih adalah Ampicilin (92,6\%), Tetracyclin $(81,25 \%)$, dan Ceftriaxon $(72,7 \%)$

\section{Saran}

a. Bagi pihak RSUD Prof. Dr. W.Z.Johannes Kupang dapat membuat pola kuman penyebab ISK, sehingga dapat dilakukan pengkajian ulang tentang terapi ISK di Rumah sakit untuk meminimalkan kejadian resistensi bakteri terhadap antibiotik

b. Untuk penelitian selanjutnya perlu dilengkapi dengan data sekunder yaitu rekam medik pasien untuk mengetahui terapi yang digunakan oleh pasienm sehingga bisa mencocokan kesesuain terapi antibiotik pada pasien.

\section{DAFTAR PUSTAKA}

Amin, M., Mehdinejad, M., \& Pourdangchi, Z. (2009). Study of bacteria isolated from urinary tract infections and determination of their susceptibility to antibiotics. Jundishapur Journal of Microbiology, 2(3), 118-123.

Badan, P. (2011). Gunakan Antibiotik 
Secara Rasional untuk mencegah kekebalakuman. Jakarta:

Kementerian Kesehatan RI

G. Katzung, B., B. Masters, S., \& J.

Trevor, A. (2012). Basic \&

Clinical Pharmacology (12th ed.).

New York: The McGraw-Hill

Companies, Inc.

Hilaria, M., Elisma, E., Yuliani, N., \& M., S. (2018). Antibiotics sensitivity to the patients with urinary tract infection in Prof. Dr. W. Z. Johannes hospital. Asian Journal of Pharmaceutical and Clinical Research, 11(Special Issue 1), 171-173.

https://doi.org/http://dx.doi.org/10. 22159/ajpcr.2018.v11s1.26599

Kuswandi. (2011). Resistensi Bakteri terhadap Antibiotika Kian Meningkat. Retrieved from http://farmasi.ugm.ac.id/v1/berita149-prof-kuswandi--resistensibakteri-terhadap-antibiotika-kianmeningkat.html

Rahmawati, Y. (2015). Peta Kuman Dan Resistensinya Terhadap Antibiotika Pada Pasien Faringitis Di RSUD Dr. Moewardi Tahun 2014. UNIVERSITAS MUHAMMADIYAH SURAKARTA.

Tjay, T. H., \& Rahardja, K. (2007). Obat-Obat Penting. Jakarta: PT.Elex Media Komputindo Kelompok Gramedia. 